\title{
Til forsvar for barns spontane lek
}

\section{Einar Sundsdal ${ }^{\star}$ og Maria Øksnes, ${ }^{1}$}

\begin{abstract}
Sammendrag
Barndommens far, Jean-Jacques Rousseau (1712-1778), og senere, barnehagens grunnlegger, Friedrich Frøbel (1782-1852), var begge opptatt av barndom og barns mulighet til å tape tid. Dette ble betegnet som negativ pedagogikk og innebar blant annet at barn skulle fordrive tiden med det som passet for barn: lek. Barna skulle få holde på for seg selv, voksne skulle ikke bedrive undervisning, men la barn oppdage verden selv. Disse tankene har vært sentrale for vår moderne forestilling om barndom, og de har vært premissgivende for Barnekonvensjonen som slår fast at alle barn har rett til å leke. Også i dag har leken en sentral posisjon når vi snakker om barndom, men nå knyttes den til en forestilling om å vinne tid. Barn blir nå skjøvet fremover slik at de ikke skal kaste bort tiden - tape tiden - men utnytte den mest mulig effektivt med tanke på et fremtidig resultat. Denne logikken har bidratt til at FN i 2013 gikk ut og advarte om at barns rett til lek er truet. I denne artikkelen vil vi forfølge FNs forsvar for barns spontane lek. Vi vil gjøre dette blant annet ved å vise at lekens egenverdi står stadig sterkere innen en rekke forskningstradisjoner.
\end{abstract}

Nøkkelord: barns spontane lek; institusjonalisering; UN General Comment No. 17; leringstrykk; lekforskning

Received: March 2015; Accepted: March 2015; Published: April 2015

\section{Institusjonalisering av leken}

I denne artikkelen vil vi drøfte barns mulighet til å leke fritt og spontant. Denne problemstillingen er ikke ny. Allerede Jean-Jacques Rousseau, gjerne omtalt som barndommens far, la et fundamentalt nytt grunnlag for hvordan vi tenker om barndom i moderne tid. Med Emile - eller om oppdragelse (Rousseau 2010/1762) artikulerer Rousseau ikke bare en annerledes oppdragelse, men en prinsipielt annerledes oppdragelse. Skrevet som en roman radikaliserer Emile selve oppdragelsesbegrepet. Av særlig betydning er det at han formulerer «barnets naturlige egenret til barndommen» (von Oettingen, 2001, s. 18, se også Noddings, 2012; Steinsholt, 2008). Det betyr blant annet at barndommen er en selvstendig fase i livet, forskjellig fra voksenlivet. Barndom hos Rousseau ble beskrevet som en vernet sfære. Friedrich Frøbel videreutviklet Rousseaus tanker om barndom og grunnla barnehagen. Til tross for hans bidrag til institusjonaliseringen av barndommen er Frøbel en viktig talsmann for barns rett til fri

^Korresponderende forfatter: Einar Sundsdal, Avdeling for lærer- og tolkeutdanning, Høgskolen i Sør-Trøndelag, E. C. Dahls gate 2, 7012 Trondheim, NORGE. Epost: einar.sundsdal@hist.no ${ }^{1}$ Denne teksten bygger på (Øksnes og Sundsdal, 2014a) og (Øksnes og Sundsdal, 2014b). 
aktivitet og fri lek. I boken Die Menschenerziehung (The Education of Man), først publisert i 1898, formulerer han en pedagogisk målsetting om å oppdra barn til reflekterte og fritenkende mennesker. Han understreker behovet for å danne hele mennesket, med alle sine sider. For å få til dette holder det ikke bare å tilpasse oppdragelsen til det individuelle barnets natur og behov. Like viktig er det at de voksne ikke skynder barnet videre, men gir barnet tid til å finne veien selv (Frøbel, 2005).

Denne teksten skal ikke være en utlegning av Rousseau og Frøbels oppdragelsesteorier, men vi ønsker å minne om at deres syn på barndommens og lekens egenverdi har vært sentrale for pedagogiske diskusjoner både i Europa og i Nord-Amerika (jf. Dewey, 1956/1900). Siden Rousseau og Frøbels tid har mye skjedd med barndommen. På kort tid har barns lek blitt flyttet fra gata, fra mellom husene, fra skogen og fjæra og inn i pedagogiske institusjoner og voksenstyrte organiserte arenaer. Mange har båret på en frykt for at barns lek ikke vil ha gode vilkår innenfor institusjonelle rammer; at friheten barn har til å leke og forvalte sin egen frie tid forvitrer i takt med institusjonaliseringen. Dette gjelder så ulike forskere som Brian Sutton-Smith (1997, 2008), Peter K. Smith (2005), Alison Gopnik (2011) og Joe Frost (2010).

I boken A History of Childrens's Play and Play Environments skriver Joe Frost (2010) at mediers fokus på risiko og farer i det moderne samfunn har bidratt til å skape paranoide foreldre. Dette har blant annet ført til at de som arbeider med barn i land som USA og Storbritannia instruerer barna hvordan de skal bruke fritiden på bestemte måter og til å leke innendørs. I Norden har vi hatt tradisjon - både i den folkelige oppdragelsen og i fagpedagogikken - for å verne om barns muligheter til å leke på egenhånd uten voksnes innblanding. Vi ser imidlertid tendenser til at denne tradisjonen utfordres, både fra utdanningspolitisk hold og blant forskere. En typisk måte dette gjøres på er at man først tilsynelatende anerkjenner barns rett til lek, før man i neste øyeblikk trekker denne tilbake og sier at noe annet er viktigere. Det som er viktigere enn lek er som oftest læring. La oss gi et par eksempler. Flere barnehager i Rogaland (Norge) har de siste årene deltatt i Stavangerprosjektet som drives av forskere fra Lesesenteret ved Universitetet i Stavanger. Forskerne har blant annet funnet ut at toåringer $\mathrm{i}$ norske barnehager teller dårligere enn barn $\mathrm{i}$ andre land. I etterkant av dette, uttaler forskningsleder Elin Reikerås til Stavanger Aftenblad (15. juni 2012) at: «Dette er et tankekors fordi vi har veldig gode barnehager i Norge, der lek, omsorg og læring skal gå hånd i hånd. Få har vel et ønske om at vi skal få en skolebarnehage, men mulighetene til å lare nettopp gjennom leken er antagelig ikke så godt utnyttet som den kunne vert.» Mønsteret er altså at man først anerkjenner barnehagens tradisjon for lek og omsorg, for deretter å påpeke det uheldige $\mathrm{i}$ at lekens læringsutbyttepotensiale ikke er godt nok ivaretatt. Den samme argumentasjonen finnes blant politikere. På Foreldrekonferansen 2014, som arrangeres av Foreldreutvalget for barnehagen, uttaler den norske kunnskapsministeren Torbjørn Røe Isaksen først at «Fri lek er kjempeviktig». Den er nok likevel ikke viktig nok, for han følger opp med å slå fast at: «Men for at fri lek også skal bli leering, trenger vi voksne til a tilrettelegge» (Foreldreutvalget for barnehagen 2014). Norske politikere og forskere bekrefter med andre ord det FN (2013) advarer mot: barns frie spontane lek er truet av et økende akademisk press og læringsfokus - også i barnehagen. 
Sett fra pedagogikkens side er spørsmålet hvor lenge pedagoger klarer å holde stand mot en økende forventning fra politisk-byråkratisk hold om å organisere store deler av barns liv i læringsaktiviteter som en del av tidlig-innsats-tenkningen. Kunnskapsminister Torbjørn Røe Isaksen $(\mathrm{H})$ følger sine forgjengere i norsk politikk og fronter tanken om å sette inn læringsstøtet tidligst mulig. Et av argumentene handler om at forskning sies å vise at læring $\mathrm{i}$ barnehagen reduserer frafallet $\mathrm{i}$ videregående skole (NRK, 10.11.14). Etter vår mening er det få som i dag stiller spørsmål ved institusjonaliseringen av barns lek og fritid; inngrep som kan forstyrre barns tid til å holde på med sine egne prosjekt. Slike inngrep betraktes derimot ofte som en mulighet for voksne til å videreføre bestemte målorienterte pedagogiske prosjekt. Både barnehage og skolefritidsordning (SFO) ser ut til å regnes som sentrale arenaer for slike prosjekt. Fra politisk hold er det økende interesse for barndommen og lekens potensial med tanke på tidlig innsats og forberedelse og støtte til skolelivet. Dette fokuset kan kanskje gjøre det vanskeligere for pedagoger å rettferdiggjøre at de lar barn leke fritt og for barn å finne rom for sin egen lek.

I denne artikkelen vil vi vise at begrensninger i barns muligheter til å leke fritt og spontant nå løftes frem som et sentralt barndomspolitisk problem. Av særlig betydning er Barnekomiteens generelle kommentar til artikkel 31 i Barnekonvensjonen. Videre vil vi vise at det fra flere ulike forskningsområder argumenteres for at leken først og fremst har egenverdi og at det å gjøre forsøk på å styre og kontrollere lek i retning av forhåndsbestemte mål, kan virke mot sin hensikt. Det er dessuten lite bevis $\mathrm{i}$ forskningen for at leken kan bidra med noe med tanke på bestemte læringsutbytter eller en særlig utvikling.

\section{Barns lek er truet}

Artikkel 31 i Barnekonvensjonen sier at «Partene anerkjenner barnets rett til hvile og fritid og til å delta i lek og fritidsaktiviteter som passer for barnets alder og til fritt å delta i kulturliv og kunstnerisk virksomhet». Barnekonvensjonen er forpliktende for de land som har ratifisert den. Det betyr at samfunn og offentlige myndigheter skal bidra til at alle barn får nyte godt av rettighetene i artikkel 31 . Frem til nå har ikke denne artikkelen hatt en kommentar knyttet til seg. FN har imidlertid sett behovet for en presisering i form av en kommentar og lanserte i 2013 "General comment No. 17 on the right of the child to rest, leisure, play, recreational activities, cultural life and the art (art. 31)". Slike kommentarer utarbeides bare når det er behov for retningsgivende tolking av enkelte artikler i barnekonvensjonen og i særlig viktige spørsmål. Kommentaren er retningsgivende for alle som arbeider med barn. De generelle kommentarene er ifølge den norske regjeringen verdifulle retningslinjer for tolkningen og anvendelsen av barnekonvensjonen (se også Øksnes og Sundsdal, 2014b). Det er verdt å merke seg at siden kommentaren kom i 2013 har den fått bemerkelsesverdig lite oppmerksomhet fra politikere og forskere både i de nordiske landene og internasjonalt.

I kommentaren til artikkel 31 beskrives mange barns hverdag som avskåret fra en selvsagt mulighet til lek. Det uttrykkes bekymring for i hvor liten grad rettighetene 


\section{E. Sundsdal og M. Øksnes}

i artikkelen anerkjennes i praksis, blant annet at det i liten grad sørges for lovgivning og nasjonal og lokal planlegging for å ivareta barns lek. For Norges del ser vi at de lokale lekeplassene for barn råtner og blir farlige på grunn av manglende vedlikehold. Løsningen er ofte å legge ned lekeplasser. Dette har skjedd i flere norske byer (f.eks. Stavanger, Porsgrunn, Bergen, Fredrikstad). Ifølge FN sliter mange land med fattigdom, krig og andre særskilte forhold som gjør det vanskelig å legge til rette for barns lek ved å investere i lekemateriell, arenaer for lek og lovgivning som skal sikre leken. I Norden er det heldigvis slik, for å låne ordene til en syrisk flyktning, at våre barn leker med leker og ikke med rester etter bomber og granater. Den typen trusler fattigdom og krig utgjør mot barns rett til lek er selvfølgelig av en helt annen karakter enn den som gjelder nordiske barn.

FN tegner likevel et tydelig trusselbilde som gjelder for barns lek i velferdsstater som våre. Dette bildet viser at når det først investeres i lek i vår del av verden er det $\mathrm{i}$ hovedsak strukturerte og organiserte lekaktiviteter det er snakk om. Årsaken til dette utdypes på følgende måte:

I mange deler av verden anses lek som bortkastet tid, som tid brukt på useriøs og
uproduktiv aktivitet uten egenverdi. Foreldre, profesjonelle omsorgsytere og ansatte
i offentlig forvaltning rangerer læringsarbeid eller arbeid for penger høyt, mens lek
ses på som noe bråkete, skittent, forstyrrende og ødeleggende. I tillegg mangler ofte
voksne den tryggheten, evnen og forståelsen som kreves for å kunne støtte opp om
barns lek og for å kunne være sammen med dem på en leken måte. Både barns rett
til å delta i lek og tidsfordriv, og den grunnleggende rollen det spiller for deres velvære,
helse og utvikling, er lite forstått og lite verdsatt (FN, 2013, s. 11, vår oversettelse).

Oppmerksomheten rettes altså mot et behov for å sikre dagens barn tid og rom til spontan lek. Lek beskrives da som en del av deltakelsen i hverdagslivet og det påpekes at den har egenverdi i den forstand at den for barnet representerer forlystelse, moro og fornøyelse for dets egen skyld. Helt konkret advares det mot at et stigende læringstrykk og vektlegging av formell akademisk suksess marginaliserer lek for lekens egen skyld. I Norge ser vi eksempel på at barnehagen og småskolen i økende grad fokuserer på akademiske mål og formell læring på bekostning av lek, og at både dagsrytme og læreplan ofte ikke gjenspeiler at det er nødvendig å gi tid og rom for barnas frie lek.

\section{Leketid blir til undervisningstid}

Internasjonalt har det over lengre tid eksistert et ønske om å minske leketid og maksimere tiden til undervisning i skole og barnehage (Smith, 2010). I Norge har ulike interessegrupper vært opptatt av at barnehagen må bli mer «pedagogisk» i den forstand at den skal vektlegge formell læring og støtte skolens oppgaver. La oss ta et blikk på den nære norske historien som illustrerer hvordan man formelt innskrenker rommet for barns lek.

I stortingsmeldingen Kvalitet $i$ barnehagen (2008-2009) fremheves det at barnehagen som læringsarena skal styrkes, og i Rammeplan for barnehagens innhold og oppgaver fokuseres det i stor grad på barnehagen som lærings- og skoleforberedende arena. 
En evaluering av implementeringen av rammeplanen peker på at ansatte i barnehager i mindre grad vektlegger lek etter innføringen av ny rammeplan: leken kommer i skyggen av arbeidet med læring. Evalueringen dokumenterer et økende fokus på formell faglig læring og kartlegging av enkeltbarns faglige ferdigheter (Østrem m.fl., 2009).

Den senere tiden har det planlagte Agderprosjektet, i Norge, utfordret forestillinger om hva livet i barnehagen skal handle om. Prosjektet har da også møtt skarp kritikk for å bevege seg altfor langt bort fra det som oppfattes av mange som barnehagens egenart. Forskerne bak det planlagte prosjektet ivrer blant annet etter å definere læringsmål for barna (femåringene) og undersøke effekten av formell læring og veiledet lek. Det hele legitimeres med forberedelse til livet i skolen og tidlig innsats (jf. en rekke oppslag i regionalavisen for Agder, Fædrelandsvennen og i den landsdekkende Aftenposten).

Et annet eksempel på hvordan leketid blir undervisningstid ser vi i forbindelse med at alderen for skolestart for norske barn ble senket fra 7 til 6 år i 1997. Da forslaget om at 6-åringen skulle flyttes fra barnehagen til skolen som en utvidelse til et 10-årig grunnskoleløp, kom det sterke protester fra flere hold. For å roe ned foreldre og en rekke fagfolk ble det lovet at det første skoleåret skulle ha lek som hovedgeskjeft. I 2006 kom det en ny læreplan, Kunnskapsløftet, og det ble raskt klart at her stod læring i høysetet. Sammenlignet med L97 er lekens rolle tonet betraktelig ned. For eksempel strøk daværende utdannings- og forskningsminister Kristin Clemet $(\mathrm{H}) \mathrm{de}$ 247 timene som var satt av til fri aktivitet i L97, timer der man kunne tenke seg at leken inngikk. Dette skjedde uten protester fra partiene som i sin tid vedtok L97. Et annet eksempel er at førskolelæreren (nå: barnehagelæreren) i forbindelse med senkning av skolealderen ble lovet sin plass i skolen for å ivareta det beste fra barnehagen, nemlig leken. En konsekvens av at leken ble nedtonet i Kunnskapsløftet er at dørene til skolen gradvis ble lukket for barnehagelærere gjennom endring av kompetansekrav. ${ }^{2}$ Det var mange i Norge som fryktet at det bare var retorikk da leken ble lovd en plass i skolen, og deres bekymring ser ut til å ha vært berettiget (Øksnes, 2010).

Vi ser at også når det gjelder skolefritidsordningen (SFO), får virksomheten i hovedsak oppgaven med å underbygge skolens kultur og pedagogikk. Et godt eksempel på det er hvordan de sentrale skolefagene gjenspeiles i målene for Aktivitetsskolen (SFO) i Oslo. I debatten om heldagsskole ser man forøvrig konkret for seg en gradvis utvidelse av skoledagen for 1. til 4. klasse. Vi har havnet i en situasjon der det viktigste er at barn gjør sine lekser - deretter kommer, dersom det er tid igjen, muligheten til å være sammen med venner og leke. Det er snakk om en utvikling der barns frie tid - det FN kaller tid til tidsfordriv og som Rousseau og Frøbel kalte å tape tid - blir stadig mindre. Dette gjelder også for de yngste barna, som vi allerede har

\footnotetext{
${ }^{2}$ Kunnskapsdepartementet, ledet av en statsråd fra SV, fastsatte i 2008 endringer i forskrift til opplæringsloven om kompetansekrav til lærere i grunnskolen. Endringene innebar at førskolelærere som skal tilsettes $\mathrm{i}$ skolen må ha tilleggsutdanning. Med de nye kravene kan ingen skoleeiere framover tilsette førskolelærere på første årstrinn uten at disse har minst ett års tilleggsutdanning rettet mot undervisning på barnetrinnet.
} 
pekt på: Det som i utgangspunktet skulle være tid for lek gjøres om til undervisningstid. Leken er nærmest forsvunnet fra læreplanen for skolen. I Rammeplan for barnehagen og i utdyping av formål for SFO er det fortsatt belegg for at leken har en sentral posisjon, men det er svakt formulert med tanke på at den stort sett betraktes som et fundament og middel for barns læring. Hva innebærer en slik tenkning mer konkret?

\section{Pedagogikkens tidsalder}

For å kunne sikre og gi leken en begrunnet plass i våre utdanningsinstitusjoner har man ansett det som nødvendig å knytte den til læringsrelevante erfaringer eller en form for pedagogisk ønsket utvikling. Dette burde ikke komme som en overraskelse innenfor et pedagogisk klima som er stadig mer opptatt av resultater, målinger, testing og accountability (Hopmann, 2008). Denne formen for målorient pedagogikk har vi ikke mye erfaring med i norske barnehager, men de siste årene har det blitt gjort erfaringer med sterk målorientering i skolen. I en stor rapport om læreres praksis og tenkning etter innføringen av Kunnskapsløftet advarer forskerne nå mot målorienteringens konsekvenser: «Utvikling av konkrete læringsmål for avgrensede deler av undervisningsarbeidet, kombinert med detaljerte vurderingskriterier og hyppig testing av elevene, kan i enkelte tilfeller føre til et forfeilet syn på undervisning og lede til en negativ fragmentering av læringsarbeidet» (Hodgson, Rønning \& Tomlinson, 2012, s. 186).

Alison Gopnik, en av verdens fremste forskere på barns kognitive utvikling, er blant dem som er bekymret for lekens vilkår i dagens samfunn. Hun har reist skarp kritikk mot det økende læringspresset i barnehagen og på andre arenaer der barn lever sine liv. Ifølge Gopnik lever vi nå i «pedagogikkens tidsalder», noe som innebærer at også foreldre i økende grad instruerer sine barn i stadig yngre alder (Gopnik, 2011). Foreldre legger også press på pedagoger til å gjøre barnehagen stadig mer lik skolen. Det samme gjør politikere når de vedtar lover som innebærer mer formell læring i barnehager. Som kognisjonsforsker er ikke Gopnik bare bekymret for barns mulighet til å leke fritt og spontant - hun frykter også for den spontane og frie læringen. Hun er redd for at barns muligheter til spontane læringssituasjoner skal forvitre, og at barna skal miste rike, stabile, trygge omgivelser med omsorgsfulle og støttende voksne til fordel for direkte instruksjon eller undervisning, noe hun mener begrenser barns læring. Med andre ord viser ny kunnskap om barns kognitive utvikling at det er en feilslutning å tro at bruk av formelle og målorienterte metoder gir mer eller bedre læring for små barn, tvert imot (Bonawits m.fl., 2011; Buchsbaum m.fl., 2011).

Det som kan aksepteres som lek i pedagogikkens tidsalder ser altså ut til å være en lek som kan tjene en bestemt oppgave i forhold til å nå bestemte forhåndsoppsatte mål. Den leken som de voksne anser som legitim er den leken som er fornuftig, nyttig og god og som kan betale seg i formell forstand. Det er en lek som ikke har noen egenverdi, men som er et middel for å oppnå en pedagogisk målsetning. Det er en lek som er voksenorganisert, formalisert, forutsigbar og strukturert - den er tilrettelagt av voksne for også å bli læring for å parafrasere Røe Isaksen. Denne forståelsen av lek 
underbygges av enkelte forskere som har hatt en tendens til å beskrive lek som noe entydig, til å forstå den som noe som kan bidra til barns læring og utvikling, til å redusere den til noe som kan fungere som et pedagogisk instrument for noe annet enn lek. I mange tilfeller viskes nærmest forskjellen mellom lek og læring ut og blir det samme. Det ser ut til å dreie seg om en tro på at leken lar seg styre av både barn og voksne inn mot bestemte pedagogiske mål, at vi kan planlegge eller forutsi hva som skal komme ut av den - en beskrivelse av lek som sjelden har til hensikt å la barn leke $\mathrm{i}$ fred.

Lek for sin egen del, som noe verdifullt i seg selv, synes med andre ord å være så undervurdert $\mathrm{i}$ vår kultur at det å leke kun blir rettferdiggjort når leken er «pedagogisk nyttig» $\mathrm{i}$ en eller annen forstand. Det er dette Gopnik sikter til når hun sier vi lever i pedagogikkens tidsalder. FN utdyper dette når det i kommentaren pekes på at for mange barn begrenses rettighetene $\mathrm{i}$ Barnekonvensjonen av voksenledede aktiviteter som fører til lite eller ingen tid til selvinititerte aktiviteter eller lek.

\section{Lekens egenverdi}

Det presiseres i kommentaren fra $\mathrm{FN}$ at barn har rett til tid for seg selv der ingen voksne organiserer eller kontrollerer dem. Det handler om en tid der barna kan være frie fra ethvert krav, frie til å gjøre "ingenting". Den lek som kommentaren vurderer å være under press - og som Barnekonvensjonen er ment å beskytte - er den leken som har en egenverdi for barnet. Lekens egenverdi knyttes da til den mer eller mindre umiddelbare glede og lykke, fornøyelse og velbehag barn finner i den. Det er altså en forståelse av at lek ikke er et middel for noe annet, slik den heller ikke er noe som kan eller skal settes i resultat. Leken er sitt eget særegne fenomen, mangfoldig i sitt vesen, og noe som er verdifullt i sin egen rett.

FNs kommentar gjør det tydelig at vi voksne mangler en forståelse som gjør oss i stand til å støtte barns lek og samspille med dem på en leken måte. I tillegg understrekes det at den betydningen lek har for barns velvære er underkommunisert og dårlig forstått. Norden er nok intet unntak i så måte. Vi lever også i pedagogikkens tidsalder og står midt i en situasjon der pedagoger presses til å gjøre barnehager mer lik skoler, der politikere krever mer formell læring i barnehager og der leken formelt sett er på full fart ut av småskolen.

Den bekymringen som FN uttrykker i forhold til barns lek har enkelte lekforskere gitt uttrykk for i mange år. Fremst blant disse er pedagogikkprofessor Brian SuttonSmith. Han hevder at utviklingen som truer barns frie og spontane lek kan knyttes til en bestemt retorikk som i lang tid har preget lekforskningen. Professor i psykologi Peter K. Smith (2005) underbygger dette og hevder at det var en betydelig interesse for lekens rolle i barns utvikling blant psykologer og pedagoger allerede fra 1920årene og fremover. Beskrivelser av lek fremsto som naturlige $\mathrm{i}$ disse beskrivelsene selv om perspektivene hovedsakelig dreide seg om å oppfordre til verdsatt atferd og designe læringsmiljøer som fremmet et ønsket utbytte. Lekens egenverdi ble i liten grad fremhevet. Smith (2005) mener det er grunn til å stille spørsmål ved hvor god 


\section{E. Sundsdal og M. Øksnes}

mye av denne forskningen var. Det er uansett ikke til å komme unna at den i stor grad har påvirket den vanlige, folkelige måten å oppfatte og verdsette lek på.

Den mest spennende lekforskningen i dag tematiserer leken som et mangfoldig fenomen og forskningen selv kjennetegnes av å være åpen, utforskende og selvkritisk. Gordon Burghardt, en av verdens ledende forskere på atferd og følelser hos dyr, kan stå som eksempel på denne nyorienteringen innen lekforskningen. Etter Burghardts formening er det mye vi ikke vet sikkert om lek. Vi vet ikke hvordan lek er ledet av indre emosjonelle og motivasjonelle faktorer eller av miljømessige faktorer. Vi vet ikke hvilke former for leklignende atferd som er basert på bestemte prosesser i hjernen. Vi vet ikke hvor mye eller hva slags lek som er nyttig for riktig utvikling av atferdsmessig eller psykologisk helhet. En ting er han sikker på: det er like uvitenskapelig som overmodig å hevde at «lek er sentralt for all læring $\mathrm{i}$ barndommen og derfor må leken tilrettelegges på alle nivå» (Burghardt, 2005, s. 114). Verdens fremste lekforsker inntar med andre ord diametralt motsatt standpunkt enn den norske kunnskapsministeren hva angår voksnes tilretteleggelse av barns lek.

I sin epokegjørende bok om lekens opprinnelse argumenter Burghardt (2005) for at leken, til tross for hva mange tror eller håper, ikke primært representerer en såkalt fremtidsrettet praksis som skal gjøre den som leker klar for livet. Lek er viktig av helt andre grunner, og mer og mer forskning taler for at forskere som Sutton-Smith er på riktig spor når de fremhever at det som er mest åpenbart - og viktig! - med lek, er at det er en veldig spennende og morsom aktivitet som deltakerne driver med bare fordi de liker å holde på med det de gjør (Sutton-Smith, 2008). Det handler altså om lekens egenverdi. Et av de mest kjente eksemplene på lekens egenverdi kommer fra nevrobiologisk atferdsforskning og handler om aper som leker seg med å hoppe opp i lufta og gjøre forskjellige krumspring. I boken The Playful Brain beskriver Sergio og Vivien Pellis (2009) de hoppende makake-apene. For mange vil nok dette eksempelet være overraskende med tanke på at atferdsforskningen tradisjonelt har vurdert lek som en fremtidsorientert praksis som har livets rett på grunn av sine langsiktige fordeler. Det er nettopp dette synet på lek dagens lekforskning utfordrer.

Pellis og Pellis var tidligere overbevist av den såkalte praksishypotesen om lek, altså hypotesen om at lek er en praksis deltagerne deltar i for å øve seg på å takle lignende situasjoner som vil dukke opp i fremtiden. Etter at de i flere år hadde studert om det faktisk er sånn at lekeslåssing som en slags øvelsespraksis gjør at rottebarn blir bedre til å slåss som voksne, ble de mer og mer usikre på praksishypotesens forklaringskraft. De begynte også å tvile på de forklaringer som sa at lek er essensielt for å videreutvikle og forfine kognitive og sosiale evner. Når det gjelder lekeslåssing, hevdet de at det er noe verken rotter eller andre dyr gjør for å forbedre sine motoriske, kognitive eller sosiale evner, men fordi de lærer hvordan de kan justere og tilpasse - kalibrere - sine emosjonelle reaksjoner til en uforutsigbar verden. Men de slutter ikke der: De peker på at kalibrering er utilstrekkelig for å forklare all den underlige lekatferden som finnes over hele naturen. For eksempel observasjoner av hvordan to unge makake-aper i Indonesia hoppet etter en gren som stakk ut fra et tre. De to apene møttes på en sti som var dekket over av grenene fra noen trær, nesten som ei løvhytte. Begge apene la merke til en gren som var litt lavere enn de andre og 
de begynte å hoppe etter tur for å få tak i grenen. Når dyrene huket seg sammen, siktet og hoppet mot greina strakte de ut en arm, og forsøkte helt tydelig å få tak i den. De gjentok flere slike hopp etter hverandre. Hopp som var veldig like og som resulterte i små forskjeller i hoppenes kraft og høyde. Men så skjer det noe. Etter som hoppingen skrider frem blir hoppene mer og mer løsrevet fra det som opprinnelig var målet med hoppingen, nemlig å få tak i grenen. Apene begynner nå å legge til merkelige og karakteristiske elementer til hvert hopp, for eksempel sprer de bakbena eller krummer ryggen. Disse karakteristiske elementene har altså ingenting å gjøre med hvordan apene kan lykkes med å nå grenen, og heller ingenting med en kalibrering av bevegelsene i den hensikt å oppnå en funksjonell handling. Pellis og Pellis må derfor spørre seg hva som kan være grunnen til denne hoppingen? Hvorfor holdt apene på slik? Hvorfor hopper de opp i lufta med sprikende ben og krum rygg? For at kalibrerings- eller praksishypotesen skulle kunne forklare denne leken kunne ikke de elementene som apene begynte å legge til i hoppene gjøre måloppnåelsen - få tak i greina - umulig, men det er nettopp det den gjør. Så en forklaring som støtter seg på kalibrering eller øvelse for å takle en fremtidig utfordring vil ikke være holdbar. Den forklaringen forskerne står igjen med er mye enklere: apene hoppet på den karakteristiske måten simpelthen fordi de kunne - ja kanskje «av ren og skjær glede over å få det til» (Pellis \& Pellis, 2009, s. 166). Leken synes å ha en iboende verdi og å være tilfredsstillende i seg selv. Fra et nevrovitenskapelig synspunkt fremstår lekens natur mer og mer å være noe man deltar i «for dens egen skyld», selv om man foreløpig ikke har funnet det underliggende omløpet i nervesystemet som driver denne formen for gledefylt aktivitet. Forskerne erkjenner at oppfatningen av lek som selv-tilfredsstillende utfordrer mye etablert kunnskap og stiller opp nye spørsmål, men erkjennelsen kan ikke oversees.

\section{Rett till lek og barndom}

I en nylig utkommet bok om internasjonal barnerett skriver jusprofessor Trevor Buck forhåpningsfullt om at FNs General Comment No. 17 «kanskje i fremtiden vil stimulere til en mer engasjert implementering av barns rett til lek og fritid» (Buck, 2014 , s. 205). En av grunnene til optimisme er at han anser det som særlig viktig at FN gjennom sine begrepsanalyser rammer inn og tegner opp grensene for hva Barnekonvensjonen er ment å beskytte. Når det gjelder lek er den rammet inn som en sentral del av deltakelsen i hverdagslivet. Den leken Barnekonvensjonen gir rett til er den som for barn representerer forlystelse, moro og fornøyelse for sin egen skyld. Det er innenfor disse grensene - som trekkes rundt lekens egenverdi - vi skal forstå lek. Dette ser ikke ut til å være den leken en del politikere og forskere er opptatt av. For barnehageforskerne ved Universitetet i Stavanger er det beklagelig at leken ikke blir «så godt utnyttet som den kunne vært» (Stavanger Aftenblad, 15.06.12) slik at norske to-åringer kan bli like gode til å telle som to-åringer i andre land. Det er heller ikke den læringsfremmende leken som er tilrettelagt av voksne - den som kunnskapsministeren ønsker seg - Barnekomiteen er bekymret for. Tvert imot. Denne typen lek faller utenfor de grensene FN trekker rundt hva barns lek er. 


\section{E. Sundsdal og M. Øksnes}

Den leken som for barn bare er morsom og som ikke har noen mål utenfor seg selv er satt under press av den 'leken' som skal gi forskerne og politikerne mer læring og telling for de små. FN advarer helt konkret mot at økende læringstrykk og vektlegging av formell akademisk suksess kan føre til manglende anerkjennelse av barns rettigheter slik de er nedfelt i Barnekonvensjonen.

Vi vil gjerne dele Bucks optimisme på vegne av barns rett til lek og fri tid. Det er derfor gledelig å se at engasjementet på lekens vegne kommer fra uventet, men sterkt forskningsmessig hold. De mange engasjerte lærere og barnehagelærere får kanskje ikke mye støtte fra nordiske læringsforskere når de ønsker å respektere Barnekonvensjonen og la barna få leke fritt og tape tid. De har imidlertid tungtveiende støtte ikke bare fra eksperter på barnerett, men også fra internasjonal psykologisk og biologisk lekforskning.

\section{Forfatterpresentasjoner}

Einar Sundsdal, Phd, er førsteamanuensis i pedagogikk ved Avdeling for lærer- og tolkeutdanning, Høgskolen i Sør-Trøndelag. Sundsdal forholder seg i sitt arbeid til noen sentrale begreper og problemer i pedagogikken og pedagogisk tenkning. I sin forskning har han vært særlig opptatt av danningsteoretiske problemstillinger.

Maria Øksnes, Phd. i pedagogikk, er ansatt ved Program for lærerutdanning, NTNU. Hennes forskningsinteresser er først og fremst knyttet til barn, barndom og lek. I sin forskning har Øksnes også tatt opp emner som klasseledelse, demokrati og motstand, arbeid og fritid, rådgivning og improvisasjon, i tillegg til utdanningspolitikk og lærerutdanning.

\section{Referanser}

Bonawits, E., Shafto, P., Gweon, H., Chang, I., Katz, S., \& Schulz, L. (2011). The double-edged sword of pedagogy: Instruction limits spontaneous exploration and discovery. Cognition, 120(3), 322-330.

Buchsbaum, D., Gopnik, A., Griffiths, T. L., \& Shafto, P. (2011). Children's imitations of causal action sequences is influenced by statistical and pedagogical evidence. Cognition, 120(3), 331-340.

Buck, T. (2014). International child law. New York: Routledge.

Burghardt, G. (2005). The genesis of animal play. Cambridge, MA: The MIT Press.

Dewey, J. (1956/1900). The school and society. Chicago, IL: The University of Chicago Press.

Foreldreutvalget for barnehagen. (2014). Spekket og spennende Foreldrekonferanse Retrieved March 23, 2015, from http://www.fubhg.no/spekket-og-spennende-foreldrekonferanse.5604987-206775.html

Frøbel, F. (2005/1898). The education of man. New York: Dover.

Frost, J. (2010). A history of children's play and play environments. New York: Routledge.

Gopnik, A. (2011). Why preschool shouldn't be like school. Slate Retrieved March 16, 2015, from http://www. slate.com/articles/double_x/doublex/2011/03/why_preschool_shouldnt_be_like_school.html

Hodgson, J., Rønning, W., \& Tomlinson, P. (2012). Sammenhengen mellom undervisning og laring. (NF-rapport nr. 4). Bodø: Nordlandsforskning.

Hopmann, S. (2008). No child, no school, no state left behind: Schooling in the age of Accountability. Fournal of Curriculum Studies, 40(4), 417-456.

Kunnskapsdepartementet. (2009). St.meld. nr. 41: Kvalitet i barnehagen. Oslo: Kunnskapsdepartementet.

Kunnskapsdepartementet. (2011). Rammeplan for barnehagens innhold og oppgaver. Oslo: Kunnskapsdepartementet.

Noddings, N. (2012) Philosophy of education. Boulder, CO: Westview Press.

NRK. (2014, November 10) Daniel (1) gjør som kunnskapsministeren vil. Retrieved March 23, 2015, from http:// www.nrk.no/rogaland/onsker-mer-laering-i-norske-barnehager-1.12029462

Pellis, S., \& Pellis, V. (2009). The playful brain. Venturing to the limits of neuroscience. London: Oneworld.

Rousseau, J.-J. (2010/1762). Emile - eller om oppdragelse. Oslo: Vidarforlaget.

Smith, P. K. (2005). Social and pretend play in children. In A. D. Pellegrini \& P. K. Smith (Eds.), The nature of play (pp. 173-209). New York: The Guilford Press.

Smith, P. K. (2010). Children and play. Chichester: Wiley-Blackwell. 
Stavanger Aftenblad. (2012, June 15) Norske barn teller dårligere. Retrieved March 23, 2015, from http://www. aftenbladet.no/nyheter/lokalt/stavanger/Norske-barn-teller-darligere-2989159.html

Steinsholt, K. (2008). Drømmen om Emile og Sofie. Trondheim: Tapir Akademisk Forlag.

Sutton-Smith, B. (1997). The ambiguity of play. Cambridge, MA: Harvard University Press.

Sutton-Smith, B. (2008). Play theory. A personal journey and new thought. American fournal of Play, 1(1), 80-123.

United Nations. (2013). General comment No. 17 on the right of the child to rest, leisure, play, recreational activities, cultural life and the art (art. 31). Geneve: Convention on the Rights of the Child.

von Oettingen, A. (2001). Det padagogiske paradoks — et grundstudie i almen padagogik. Århus: Klim.

Øksnes, M. (2010). Lekens flertydighet. Oslo: Cappelen Damm Akademisk.

Øksnes, M., \& Sundsdal, E. (2014a) Barns rett til lek i pedagogikkens tidsalder. Utdanning nr. 1/10. januar 2014. Utdanningsforbundet.

Øksnes, M., \& Sundsdal, E. (2014b) Lek - det som gjør livet verdt å leve! In T. H. Rasmussen (Ed.), På sporet etter lek: Lekens vilkår $i$ det moderne (pp. 66-47). Bergen: Fagbokforlaget.

Østrem, S., Bjar, H., Føsker, L. R., Hogsnes, H. D., Thorsby Jansen, T., Nordtømme, S., \& Rydjord Tholin, K. (2009). Alle teller mer. En evaluering av hvordan Rammeplan for barnehagens innhold og oppgaver blir innført, brukt og erfart (Rapport 1/2009). Tønsberg: Høgskolen i Vestfold. 